\title{
BMJ Open Societal costs of chemotherapy in the UK: an incidence-based cost-of-illness model for early breast cancer
}

\author{
Krishnali Parsekar, ${ }^{1}$ Stephanie Howard Wilsher (D) , ${ }^{1}$ Anna Sweeting, ${ }^{1}$ Anita Patel, ${ }^{2}$ \\ Richard Fordham (i) ${ }^{1}$
}

To cite: Parsekar K, Howard Wilsher S, Sweeting A, et al. Societal costs of chemotherapy in the UK: an incidence-based cost-of-illness model for early breast cancer. BMJ Open 2021;11:e039412. doi:10.1136/ bmjopen-2020-039412

- Prepublication history and additional materials for this paper are available online. To view these files, please visit the journal online (http://dx.doi. org/10.1136/bmjopen-2020039412).

KP, SHW, AS and AP contributed equally.

Received 22 May 2020

Revised 25 November 2020

Accepted 06 December 2020

Check for updates

(C) Author(s) (or their employer(s)) 2021. Re-use permitted under CC BY-NC. No commercial re-use. See rights and permissions. Published by BMJ.

${ }^{1} \mathrm{MED}$, University of East Anglia, Norwich, UK

${ }^{2}$ Anita Patel Health Economics Consulting Ltd, London, UK

Correspondence to Professor Richard Fordham, Norwich Medical School, University of East Anglia, Norwich NR4 7TJ, Norfolk, UK; r.fordham@uea.ac.uk

\section{ABSTRACT}

Aim To estimate annual societal costs associated with chemotherapy for early breast cancer in the UK. Design Mixed methods: (a) an incidence-based costof-illness model was developed of indirect costs in patients with breast cancer and carers, and estimated from diagnosis through active treatment until death; (b) interviews with stakeholders were also undertaken to understand actual experiences and impacts of these costs. Data sources Model data were collated from relevant national data sources covering general population statistics, UK cancer registries, clinical guidelines and published literature, and patient survey data. Patient and staff views were collected through semistructured interviews.

Participants Model: patients with early breast cancer receiving systemic anticancer therapy in the UK. Interviews were undertaken with women who had chemotherapy and medical practitioners involved in breast cancer care.

Results Total costs of chemotherapy in the UK economy are over £248 million. Societal productivity losses amount to £141.4 million, which includes £3.2 million associated with premature mortality, short-term and long-term work absence (£28.6 million and £105 million, respectively). $£ 3.4$ million is associated with mortality losses from secondary malignancies due to adjuvant chemotherapy. A further £1.1 million in lost productivity arises from informal care provision. Out-of-pocket costs per round of chemotherapy account for $£ 4.2$ million, or an annual average of almost $£ 1100$ per patient. Interview findings support the cost burden modelled and also highlight the impact on cognitive function of patients and how this could increase the cost burden to patients, their families and wider society. In addition, estimated costs for carer emotional well-being are $£ 82$ million in lost quality of life. Conclusion Chemotherapy use carries significant indirect costs for society, as well as patients and their carers. These wider costs and societal perspective should be considered by commissioners to ensure chemotherapy is better targeted at those who most need it and to avoid placing unnecessary costs on patients, their caregivers and wider society.

\section{BACKGROUND}

Breast cancer is the most common cancer in women and second most common cancer overall with 2 million cases per year

\section{Strengths and limitations of this study}

- First study to comprehensively assess non-health care costs associated with chemotherapy for early breast cancer.

- Inclusion of personal experience provided a valuable humanist approach to complement the study.

- The model is limited by the availability and reliability of relevant data (no actual patient-level data).

worldwide. ${ }^{1}$ In the UK, annual new cases and deaths number approximately 55000 and 11563 , respectively; $76 \%$ survive breast cancer for 10 or more years. ${ }^{2}$ Patients with invasive breast cancer will be treated with surgery followed by breast reconstruction. Most patients will require adjuvant therapy using radiotherapy, chemotherapy, endocrine therapy or a combination of these to reduce the risk of recurrence. ${ }^{3}$ Based on treatment breakdowns provided by the National Cancer Registration and Analysis Service (NCRAS), $63 \%$ and $34 \%$ of breast cancer cases diagnosed in England in 2013-2015 received radiotherapy and chemotherapy, respectively. ${ }^{4}$

Direct treatment costs, including costs associated with adjuvant chemotherapy acquisition, delivery and toxicity, are estimated to be $£ 3145$ per patient for the entire chemotherapy regimen. ${ }^{5}$ Several studies have examined the wider economic burden of cancer, ${ }^{6} 7$ including breast cancer. ${ }^{89}$ However, estimates are lacking for the societal economic burden specifically associated with chemotherapy use for early breast cancer. We address this gap by taking an incidence-based modelling approach to estimate total costs to patients, caregivers and wider society associated with chemotherapy use for early breast cancer in the UK. We also sought the views of patients and healthcare practitioners to explore and convey the context and experience of these costs. 


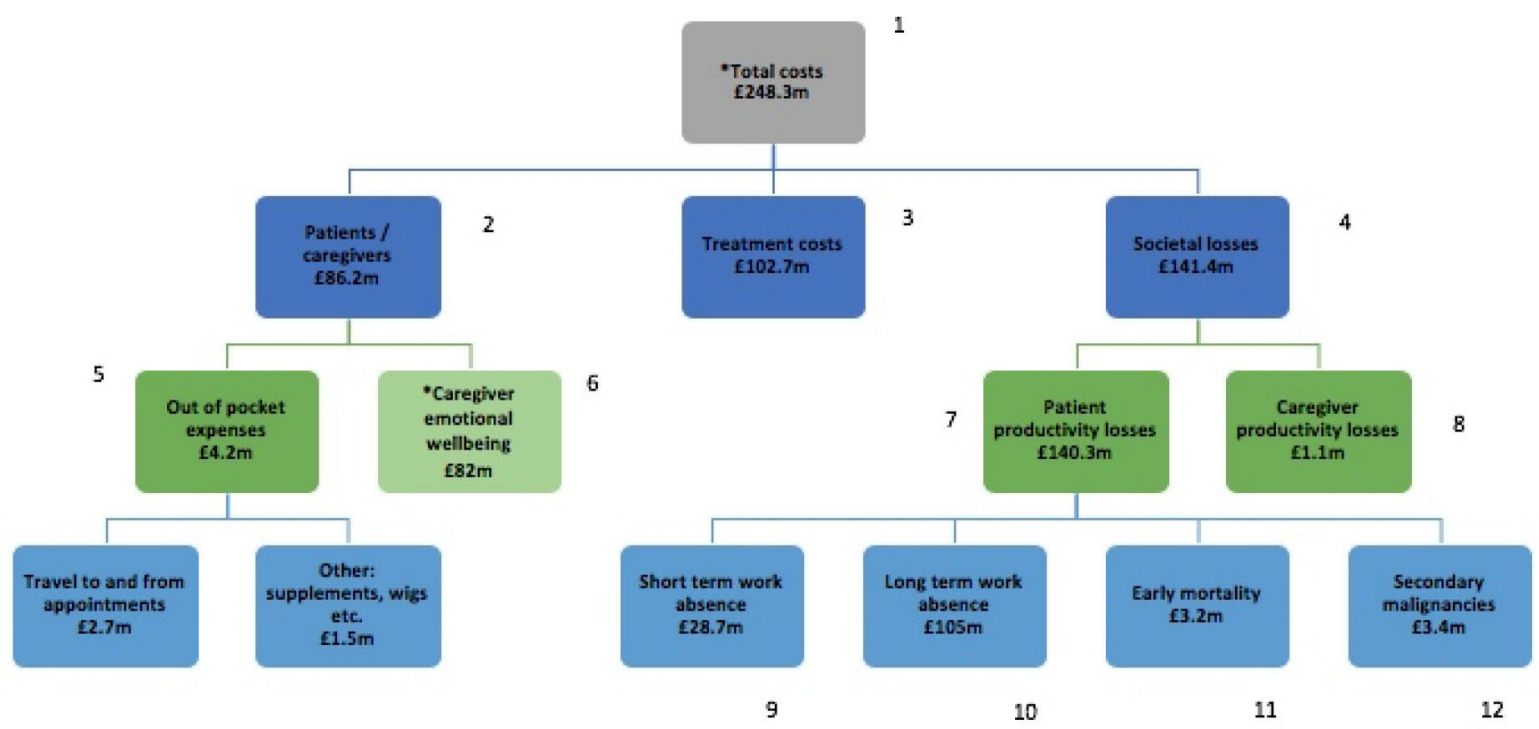

Figure 1 Overall framework for the cost-of-illness model. Items labelled 1-12 in figure 1 above are described in further detail in online supplemental table A. *Costs associated with the emotional burden of caregiving are indicative only and are excluded from the estimate of total costs.

\section{METHOD}

Patient and public participation

Patients and members of the public were not involved in the design and conduct of this study.

\section{Model: target population and time horizon}

We estimated costs for male and female patients aged 20 years and over in the UK diagnosed with early breast cancer in 2018-2019 and receiving systemic anticancer therapy (SACT). We used International Statistical Classification of Diseases and Related Health Problems-10th Revision (ICD10) diagnosis codes ${ }^{10} \mathrm{C} 50$ (malignant neoplasm of breast) and D05 (breast cancer in situ). We included patient and carer costs incurred up to 1 year following chemotherapy and productivity losses for the cohort's life span.

\section{Model: overall approach}

We developed an incidence-based cost-of-illness (COI) model in MS Excel (see figure 1 and online supplemental table A for model framework) to estimate non-treatment costs to patients/carers/society in the following categories:

- Patient and caregiver costs comprising out-of-pocket payments and the emotional burden of caregiving.

- Societal productivity losses due to:

1. Caregivers' time spent on informal care provision (short-term losses, up to 1 year, were included to capture the impact of caregiving only for the duration that patients received chemotherapy). We made this assumption so as to avoid overestimating the productivity losses.

2. Patients' short-term work absence due to treatment.

3. Patients' long-term work absence as a result of inability to return to work.

4. Patients' early mortality due to chemotherapy.

5. Patients' secondary mortality due to chemotherapyrelated secondary malignancies.
We took a 'bottom up' approach for costings and followed the Larg and Moss ${ }^{11}$ checklist for critically evaluating COI studies. Societal productivity losses (informal care; short-term and long-term work absence; early and distant mortality) were valued using the human capital approach. Informal care was additionally valued from the caregiver perspective using published estimates and shadow pricing for carers' emotional burden. The latter being a novel approach, we did not include this cost in the total costs. We also outline treatment costs falling to the health service for context.

\section{Model: inputs and analyses}

A series of focused searches was conducted to identify relevant data. Model inputs are summarised in table 1 and detailed in online supplemental tables A-F.

\section{Incidence}

Country-specific breast cancer incident cases were estimated for ICD-10 codes C50 and D05 by combining population estimates with relevant age-specific and gender-specific incident cases from relevant national cancer registration statistics: Office for National Statistics-England, ${ }^{12}$ Information Services Division-Scotland, ${ }^{13}$ Welsh Cancer Intelligence and Surveillance Unit-Wales ${ }^{14}$ and Northern Ireland Cancer Registry. ${ }^{15}$ The number of patients with early breast cancer receiving chemotherapy for curative intent was then estimated by applying national percentages of relevant tumours diagnosed (breast, breast in situ) and receiving chemotherapy, obtained from NCRAS and the UK and Ireland Association of Cancer Registries. ${ }^{416}$

Mortality/survival

Early mortality losses were estimated for patients who died within 30 days of SACT (any cytotoxic chemotherapy; active anticancer therapies such as monoclonal 


\begin{tabular}{|c|c|c|}
\hline Description & Input & Reference \\
\hline \multicolumn{3}{|c|}{ Incidence and no of early breast cancer cases in the UK } \\
\hline England & & $\begin{array}{l}\text { Office for National } \\
\text { Statistics (ONS). Cancer } \\
\text { registration statistics, } \\
\text { England }^{12}\end{array}$ \\
\hline Scotland & & $\begin{array}{l}\text { Information Services } \\
\text { Division Scotland }{ }^{13}\end{array}$ \\
\hline Wales & & $\begin{array}{l}\text { Welsh Cancer Intelligence } \\
\text { and Surveillance Unit }{ }^{14}\end{array}$ \\
\hline Northern Ireland & & $\begin{array}{l}\text { Northern Ireland Cancer } \\
\text { Registry }{ }^{15}\end{array}$ \\
\hline $\begin{array}{l}\text { Proportion receiving } \\
\text { chemotherapy treatment }\end{array}$ & $34 \%$ & $\begin{array}{l}\text { Cancer Research UK, } \\
\text { NCRAS, UKIACR; }{ }^{\star} \text { age } \\
\text { and country-specific } \\
\text { estimates used where } \\
\text { possible) })^{2416}\end{array}$ \\
\hline \multicolumn{3}{|c|}{ 30-day mortality in chemotherapy-treated cases } \\
\hline$<50$ years & $0.03 \%$ & \multirow{3}{*}{$\begin{array}{l}\text { 30-day mortality after } \\
\text { receiving SACT in } \\
\text { England, 2015-2016 } \\
\text { (curative intent) SACT } \\
\text { dataset }^{17} \text {; smoothing } \\
\text { across age categories was } \\
\text { not undertaken }\end{array}$} \\
\hline $50-69$ years & $0.28 \%$ & \\
\hline $70+$ years & $0.54 \%$ & \\
\hline
\end{tabular}

\begin{tabular}{|c|c|c|}
\hline \multicolumn{3}{|l|}{ Cost inputs } \\
\hline \multicolumn{3}{|l|}{ Carers } \\
\hline $\begin{array}{l}\text { Total no of breast } \\
\text { cancer carers for } \\
\text { patients undergoing } \\
\text { chemotherapy }\end{array}$ & 1967 & $\begin{array}{l}{ }^{*} \text { Estimated using UK } \\
\text { population estimates }{ }^{32} \text { and } \\
\text { statistics from Macmillan } \\
\text { UK }^{26}\end{array}$ \\
\hline $\begin{array}{l}\text { No of hours of } \\
\text { employment lost by } \\
\text { carer (weekly) }\end{array}$ & 2.18 & Round et $a l^{9}$ \\
\hline $\begin{array}{l}\text { Weighted median wage } \\
\text { of carer (per hour) }\end{array}$ & $£ 9.21$ & $\begin{array}{l}\text { *Estimated using median } \\
\text { hourly wage a report in } \\
\text { ASHE table } 6, \mathrm{ONS}^{19} \\
\text { Weighted by profile of } \\
\text { cancer carers' working } \\
\text { status YouGov and } \\
\text { Macmillan Cancer } \\
\text { Support }\end{array}$ \\
\hline $\begin{array}{l}\text { Disposable household } \\
\text { income/year }\end{array}$ & $£ 19834$ & $\begin{array}{l}\text { Gross disposable } \\
\text { household income from } \\
\text { ONS }\end{array}$ \\
\hline $\begin{array}{l}\text { Coefficient for caring } \\
\text { for other member who } \\
\text { had an accident within } \\
\text { last year and can still do } \\
\text { daily activities }\end{array}$ & 0.138 & $\begin{array}{l}\text { McDonald and } \\
\text { Powdthavee. }{ }^{28} \text { We } \\
\text { have assumed these } \\
\text { coefficients apply to } \\
\text { cancer caregivers }\end{array}$ \\
\hline $\begin{array}{l}\text { Coefficient for impact } \\
\text { on real equivalent } \\
\text { household income }\end{array}$ & 0.089 & \\
\hline \multicolumn{3}{|c|}{ Patient out-of-pocket expenses } \\
\hline \multicolumn{3}{|c|}{ Travel to and from appointments } \\
\hline $\begin{array}{l}\text { Mean travel cost per } \\
\text { week }\end{array}$ & $£ 31$ & \multirow{4}{*}{$\begin{array}{l}{ }^{*} \text { Calculated for the } \\
\text { duration of chemotherapy } \\
\text { only. Estimated from } \\
\text { monthly costs reported in } \\
\text { Macmillan UK }{ }^{29}\end{array}$} \\
\hline $\begin{array}{l}\text { Probability of incurring } \\
\text { outpatient travel cost }\end{array}$ & $69 \%$ & \\
\hline $\begin{array}{l}\text { Mean parking cost per } \\
\text { week }\end{array}$ & $£ 7$ & \\
\hline $\begin{array}{l}\text { Probability of incurring } \\
\text { outpatient parking cost }\end{array}$ & $38 \%$ & \\
\hline Healthcare related & & \\
\hline
\end{tabular}

Continued

\begin{tabular}{|c|c|c|}
\hline Description & Input & Reference \\
\hline $\begin{array}{l}\text { Probability of receiving } \\
\text { OTC/prescription } \\
\text { medications }\end{array}$ & $22 \%$ & \multirow{8}{*}{$\begin{array}{l}{ }^{*} \text { Costs were extrapolated } \\
\text { to annual values based } \\
\text { on estimates provided in } \\
\text { Macmillan UK }{ }^{29}\end{array}$} \\
\hline $\begin{array}{l}\text { Mean OTC medication } \\
\text { cost per year }\end{array}$ & $£ 104.30$ & \\
\hline $\begin{array}{l}\text { Probability of receiving } \\
\text { dietary supplements }\end{array}$ & $12 \%$ & \\
\hline $\begin{array}{l}\text { Mean cost of dietary } \\
\text { supplements per year }\end{array}$ & $£ 208.60$ & \\
\hline $\begin{array}{l}\text { Probability of receiving } \\
\text { private treatment for } \\
\text { healthcare }\end{array}$ & $4 \%$ & \\
\hline $\begin{array}{l}\text { Mean annual cost of } \\
\text { private treatment for } \\
\text { healthcare }\end{array}$ & $£ 330$ & \\
\hline $\begin{array}{l}\text { Probability of receiving } \\
\text { personal care at } \\
\text { person's home }\end{array}$ & $5 \%$ & \\
\hline $\begin{array}{l}\text { Mean annual cost } \\
\text { of personal care at }\end{array}$ & $£ 139$ & \\
\hline
\end{tabular}

\section{Others-daily living (monthly costs)}

Food and drink

$£ 28.65$

$\%$ affected-food and $\quad 22$

drink

Home help

$\%$ affected-need home 25

help

Childcare

$\%$ affected-childcare

Other-clothing, hair wigs (monthly cost one-off)

\section{Wigs, hairpieces}

$\%$ affected-wigs, $\quad 10$

hairpieces

Fabric supports

$\%$ affected-fabric 5

supports

Clothing

$\%$ affected-clothing

29

Healthcare
$\begin{aligned} & \text { Direct costs for adjuvant } \\ & \text { chemotherapy per regimen }\end{aligned}$

chemotherapy per regimen

osts associated with adjuvant chemotherapy acquisition, delivery and toxicity £3145/course ${ }^{5}$

\begin{tabular}{|c|c|c|}
\hline \multicolumn{3}{|l|}{ Additional inputs } \\
\hline Discounting & $3.5 \%$ & $\mathrm{NICE}^{34}$ \\
\hline Wage growth & 3.50 & $\mathrm{ONS}^{22}$ \\
\hline $\begin{array}{l}\text { Life expectancy at } \\
\text { birth-females (UK) }\end{array}$ & 82.86 years & ONS $2018^{35}$ \\
\hline $\begin{array}{l}\text { Life expectancy at } \\
\text { birth-males (UK) }\end{array}$ & 79.18 years & \\
\hline Inflation indices & various & $\begin{array}{l}\text { ONS-inflation indices, }{ }^{36} \\
\text { PSSRU } 2018^{37}\end{array}$ \\
\hline Wage rates & various & $\begin{array}{l}\text { ONS. Earnings and hours } \\
\text { worked, age group: ASHE } \\
\text { table } 6^{19}\end{array}$ \\
\hline
\end{tabular}

Continued 


\begin{tabular}{|c|c|c|}
\hline Description & Input & Reference \\
\hline $\begin{array}{l}\text { Labour force } \\
\text { participation rate }\end{array}$ & various & $\begin{array}{l}\text { ONS. Labour market } \\
\text { participation rates by age } \\
\text { and sex, UK, 1995, 2005, } \\
2015,2017^{20}\end{array}$ \\
\hline Employment rates & various & $\begin{array}{l}\text { ONS. Table A05: labour } \\
\text { market by age group: } \\
\text { women by economic } \\
\text { activity and age } \\
\text { (seasonally adjusted) }^{21}\end{array}$ \\
\hline Paid hours & various & $\begin{array}{l}\text { ONS. Paid hours: Table } \\
\text { 6.10a ASHE } 2018^{19}\end{array}$ \\
\hline $\begin{array}{l}\text { Age-specific and age- } \\
\text { standardised relative } \\
\text { survival for acute } \\
\text { myeloid leukaemia }\end{array}$ & various & ECIS database ${ }^{18}$ \\
\hline
\end{tabular}

${ }^{*}$ Costs were calculated separately. Detailed estimation in online supplemental table B. ASHE, Annual Survey of Hours and Earnings; ECIS, European Cancer Information System; NCRAS, National Cancer Registration and Analysis Service; NICE, National Institute for Health and Care Excellence; ONS, Office for National Statistics; OTC, over-the-counter; PSSRU, Personal Social Services Research Unit; SACT, systemic anticancer therapy; UKIACR, UK and Ireland Association of Cancer Registries.

antibodies, for example, trastuzumab; targeted biological treatments such as estimated glomerular filtration rate tyrosine kinase inhibitors). The 30-day mortality outcome included death from all causes, including iatrogenic deaths or those due to disease progression. The national 30-day mortality rates post-SACT were derived from the SACT Chemotherapy Dataset- England, ${ }^{17}$ and applied to newly diagnosed patients receiving chemotherapy with curative intent. The same proportion was applied to the target population from Scotland, Wales and Northern Ireland. ${ }^{17}$ Given limited relevant data, estimates for longer term mortality were narrowed in scope to only include mortality due to two potential secondary malignancies-acute myeloid leukaemia and myelodysplastic syndrome. $^{18}$

\section{Resource use and costs}

National estimates for age-specific and gender-specific wages, labour market participation, employment and wage growth were applied to productivity and mortality losses. ${ }^{19-22}$ Days off work, patient out-of-pocket expenses, direct treatment costs and informal care quantities and costs were obtained from published literature. Estimates for the value of the emotional burden of caregiving were obtained from a published analysis of impacts on carers of accident victims; we have assumed the same estimated coefficients here for cancer carers. Where estimates were unavailable, relevant assumptions were made and tested using sensitivity analyses. This included adjustments to published estimates of patient-related costs due to travel and parking for hospital visits which varied by chemotherapy regimen, other out-of-pockets including overthe-counter medications, dietary supplements, use of private healthcare, home care, wigs, clothing and so on. Additional sensitivity analyses were performed to address uncertainty in incidence of secondary malignancy rates following chemotherapy.

\section{Model: outputs}

Costs were estimated in terms of total annual cost and average annual cost per patient, with averages calculated for relevant subgroups rather than the total target population. All costs are in 2018 British Pounds Sterling (£). Future costs were discounted at $3.5 \%$.

\section{Participant interviews: sample and measures}

Two women who had experienced breast cancer, their main carers, and two healthcare practitioners were identified and invited to participate in the study by a cancer charity. The carers declined because the experience would be too emotionally painful; all others agreed and participated in semistructured interviews covering relevant topics (table 2). Pseudonyms are used throughout to protect anonymity.

\section{Participant interviews: procedure}

Participants received an invitation letter, information sheet and consent form. Interviews were conducted by two researchers (SHW and KP) from the University of East Anglia, lasted about 1-hour long and were audio recorded. Interviews with Mary and Sue were scheduled by the cancer charity and conducted in a room in one of their centres. The interview with Mary was face-to-face.

Table 2 Demographics of participants and the topics covered in their interviews

Participants Topics covered

Women who had suffered breast cancer

1. Mary (60-70 years). Her main carer was a daughter who suffered from irritable bowel disease and had four children (aged 8-24 years).

$\begin{array}{ll}\text { 2. Sue (40-50 years) had two children (aged 15-25 years). Her } & \begin{array}{l}\text { Others' cost implications of chemotherapy (eg, loss of } \\ \text { earnings by carers, childcare) }\end{array} \\ \text { husband worked away from home during the week. } & \text { Their role with patients } \\ \text { Healthcare practitioners } & \text { Level of risk from chemotherapy treatment } \\ \text { 1. A nurse who supported women suffering breast cancer. } & \\ \text { 2. A consultant surgeon for breast cancer at a large hospital in } & \text { Effect and cost of chemotherapy treatment for patients } \\ \text { England. } & \end{array}$


Table 3 Out-of-pocket expenses during a round of chemotherapy treatment

\begin{tabular}{lcc}
\hline Out-of-pocket expenses & Total costs, $£(\%)$ & Costs/patient (£) \\
\hline Travel to and from appointments & $2700000(57)$ & 188 (based on 6 treatment visits) \\
Parking & $289372(7)$ & 209 \\
\hline Dietary supplements & $467206(11)$ & 104 \\
Over-the-counter medicines & $428272(10)$ & 330 \\
\hline Private healthcare treatment & $221733(6)$ & 139 \\
Personal care at person's home & $129717(3)$ & 34 \\
New clothes & $184897(5)$ & 25 \\
Wigs and hairpieces & $47314(1)$ & 15 \\
Fabric supports & $14400(<1)$ & 1085 \\
\hline Total & 4223538 & 25 visits) \\
\hline
\end{tabular}

The interview with participant Sue was by telephone. After the interview, each participant was debriefed and offered support by the cancer charity counselling services. Interviews with healthcare practitioners were conducted face-to-face.

\section{Participant interviews: data analysis}

Interviews were transcribed verbatim, anonymised and validated with each participant. Transcripts were thematically analysed and organised according to key themes and concepts of the study: effects of diagnosis and treatment; impact on family; work arrangements and other direct costs.

\section{RESULTS}

\section{Total patient and societal productivity costs}

Total productivity losses, out-of-pocket costs and caregiver-related non-health care costs were estimated at $£ 145$.4 million, outweighing the $£ 102.7$ million associated with direct treatment costs. This does not include the potential impact of emotional well-being of carers.

\section{Patient and caregiver costs}

Out-of-pocket expenses (table 3) during a round of chemotherapy treatment were $£ 4.2$ million. These were dominated by travel costs of $£ 2.7$ million (61\%) which varied by number of hospital visits (3-12 weeks/cycles) depending on the chemotherapy regimen (3-12 visits considering a chemotherapy regimen up to 9-12 weeks, with docetaxel every 3 weeks; or weekly/biweekly paclitaxel). Results from associated sensitivity analyses are reported in online supplemental table $\mathrm{F}$.
Emotional well-being impacts on carers were valued at $£ 82$ million. This imputed compensating income required for the provision of informal care, for a patient who can still perform daily activities, was estimated at $\sim £ 74000$ per person per year. For high dependency patients who cannot perform daily activities, the estimated compensation required is much higher at $£ 124000$ (total cost: $£ 138$ million/year).

\section{Productivity losses}

Patient productivity losses totalled $£ 140$ million (£101 200 per person) (table 4) and were dominated by longterm $(75 \%)$ and short-term $(21 \%)$ work absences.

Short-term work absence comprised:

- An estimated 7481 people undergoing adjuvant chemotherapy for early breast cancer (employed and participating in the workforce in 2017-2018, with the exception of Wales, which was based on 2016 incidence statistics).

- Approximately 320000 lost workdays while undergoing a chemotherapy regimen (10 weeks).

- An average of 39-51 days off work to undergoing chemotherapy treatment.

These base case findings were based on a standard chemotherapy regimen lasting up to 10 weeks. Alternative estimates for 9-week and 12-week regimens are provided in table 5 .

Estimates for long-term work absence suggested that:

- Approximately 5253 people (employed and participating in the UK workforce in 2017-2018, with the exception of Wales, which was based on 2016 incidence statistics) are unable to return to work over

Table 4 Total patient productivity losses

\begin{tabular}{ll}
\hline Patient productivity losses & Total cost (average per person) \\
\hline 30-day mortality cost following chemotherapy & $£ 3.2$ million (£64000) \\
Short-term work absence: time taken off work due to chemotherapy & $\sim £ 28.7$ million ( £300 500) \\
Long-term work absence: inability to return to work & $\sim £ 105$ million ( £32000) \\
Secondary malignancies: 30-day mortality following chemotherapy & $£ 3.4$ million (£64000) \\
\hline
\end{tabular}




\begin{tabular}{llll}
\hline $\begin{array}{l}\text { Table } 5 \\
\text { absence }\end{array}$ & Patient productivity losses-short-term work \\
\hline $\begin{array}{l}\text { Scenario } \\
\text { summary }\end{array}$ & Base case & Best case & Worst case \\
\hline $\begin{array}{l}\text { Duration of } \\
\text { chemotherapy } \\
\text { (weeks) }\end{array}$ & 10 & 9 & 12 \\
$\begin{array}{l}\text { Total cost/year } \\
\begin{array}{l}\text { Average cost/ } \\
\text { person }\end{array}\end{array}$ & & \\
$\begin{array}{l}\text { Total working } \\
\text { days lost/year }\end{array}$ & 320277 & 288249 & 384332 \\
$\begin{array}{l}\text { Average } \\
\text { working days } \\
\text { lost /person }\end{array}$ & 43 & $£ 3082$ & $£ 4110$ \\
\hline
\end{tabular}

3 years thereby resulting in a loss of $\sim £ 105$ million ( £33000 per person).

- Considering the working age population (<65years), the 3-year productivity loss is $£ 93$ million based on an estimate that $17 \%$ are unable to return to work following adjuvant chemotherapy. ${ }^{23}$

There were an estimated 48 chemotherapy-related deaths for all breast cancers in 2018 in the UK with a total loss of 930 life years, amounting to total early mortality costs of $£ 3.2$ million. Among these, nearly $50 \% \quad(n=23)$ were of working age $(<65$ years) with an estimated loss of 630 life years due to chemotherapy-related early mortality. Chemotherapy-related early mortality led to an estimated average productivity loss of $£ 65000$ over the lifetime. This was weighted for differences in mortality rates by sex, resulting in higher estimates for men (£98000 vs $£ 65000)$ due to differential wage rates and hours. In addition, $0.5 \%$ of cases develop secondary malignancies 5 years after receiving chemotherapy. ${ }^{24}$ We estimate associated productivity losses at $\sim £ 3.4$ million $(£ 50000 /$ per person). Five-year relative survival was used to estimate overall death rate following development of secondary malignancies. ${ }^{18}$ Varying these 5-year incidence rates for secondary malignancies from $0.3 \%$ and $1.2 \%$ resulted in alternative estimates ranging between $£ 2$ million and $£ 8$ million (table 6).

Average productivity losses due to early mortality, longterm and short-term absence and secondary malignancies, weighted by age group, are summarised in table 7 . These estimates also capture differences in wage rates and workforce participation as well as the distribution of chemotherapy-related deaths and work absence across different age groups. Those aged 45-69 years were associated with a higher proportion of productivity losses.

Total lost productivity from providing informal care was estimated at $\sim £ 1.1$ million. Carers lose over 2 hours of employment per week, ${ }^{9}$ amounting to salary losses of $£ 1000$ per year. Half of all carers are in full-time or parttime employment ${ }^{25}$ and $36 \%$ provide long-term care for more than 3 years. ${ }^{26}$ To account for long-term care, we estimated total caregiving costs as $£ 5.8$ million, over a 5 -year period of care.

\section{INTERVIEWS WITH PARTICIPANTS}

\section{Impact of treatment}

Mary and Sue had very different experiences through treatment for breast cancer. Mary was offered various options for chemotherapy treatment but did not understand all the medical implications and was too emotionally absorbed on the breast cancer to think about treatment. Sue was offered a lumpectomy but no other choice of treatment, due to the type of cancer she had. Both women were emotionally stunned by the situation and feared chemotherapy:

...my world fell apart...I felt an emotional wreck, absolutely. At the time when the surgeon told me I just cried. Yes, it was an emotional time and I knew I'd got to have chemotherapy and radiotherapy. It was very emotional, like a roller coaster. (Mary)

They both suffered the same side effects (loss of hair, eyelashes, eyebrows, tiredness). However, Sue found effects to the alimentary canal very hard to deal with as she had constipation and diarrhoea at the same time. Loss of taste was her worst side effect as this impacted on so much-eating, enjoyment of food, cooking for the family:

For threeweeks everything tasted of salt, that was hard, even water.... then after that I just couldn't taste anything...because your mouth is so dry it affects your textures so I couldn't eat bread because of the texture...you know so that was probably the most challenging thing was because you just don't want anything really... (Sue)

For Mary hair loss was the worst side effect and made her feel like 'a patient with cancer' without her wig and makeup:

I get up and look at myself in the mirror, aw, cancer patient. OK, have a shower, put my make up on, put

Table 6 Mortality losses from secondary malignancy under alternative incidence rates

\begin{tabular}{llll}
\hline Scenario summary & Base case & Best case & Worst case \\
\hline 5-year incidence of secondary malignancy & $0.50 \%$ & $0.30 \%$ & $1.20 \%$ \\
Total cost/year & $£ 3364107$ & $£ 2018464$ & $£ 8073857$ \\
Average cost/per person & $£ 49964$ & $£ 49964$ & $£ 49964$ \\
\hline
\end{tabular}




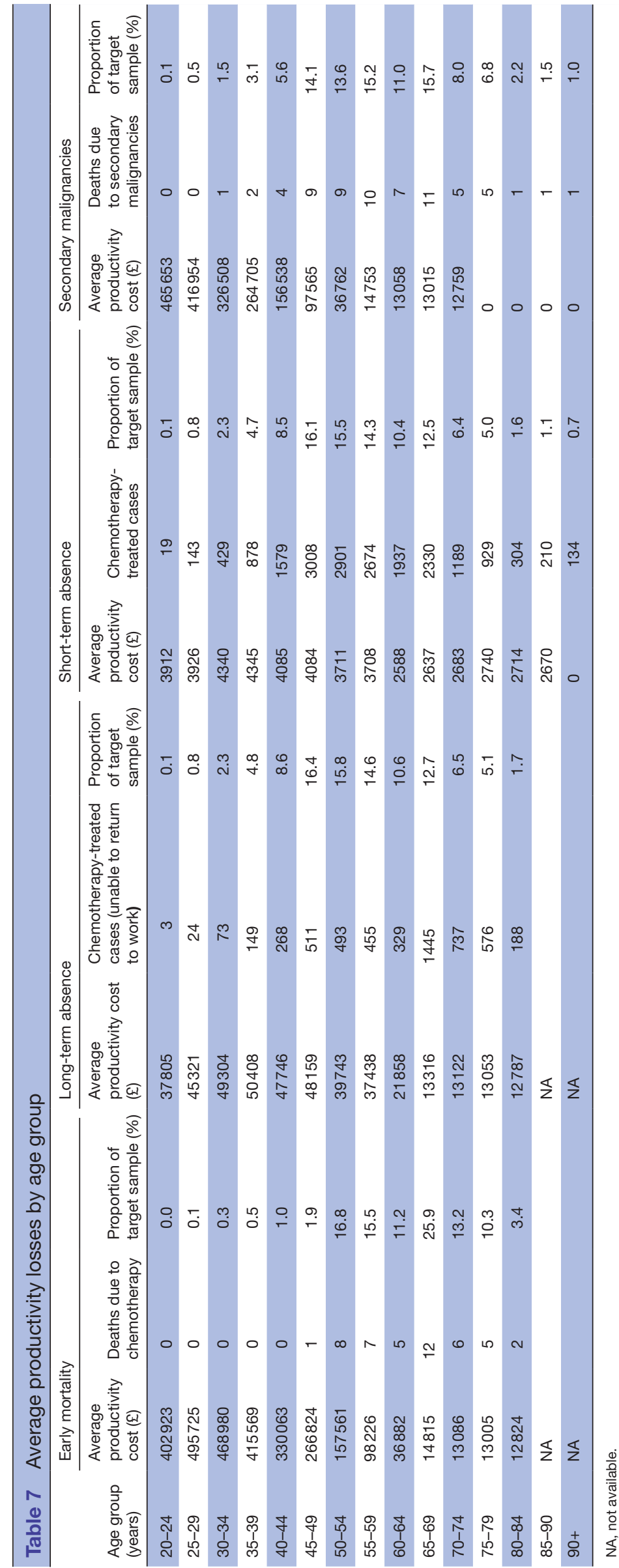


my wig on - look in the mirror. That's better, with a wig I can cope... (Mary)

\section{Informal care}

Close family members supported both women: Mary by her daughter, Sue by her husband. The burden of treatment was high on both family members as they attended all or most of the sessions. Rose, Mary's daughter, had irritable bowel disease and four children, and Mary had two dogs and a cat that needed care. Mary felt the experience impacted on her daughter:

My daughter coped very well, she wouldn't let anyone else take me (to hospital) ... and only missed two sessions of radiotherapy. Now it's behind us, I think it's hitting her. She was strong for me... I think she needs counselling.... (Mary)

Sue's children were affected, and her husband worked away during the week and so had to take leave and make considerable changes to his work pattern to accompany his wife to the hospital:

My husband works away during the week and every three weeks he is away for two weeks at a time so umm he had to obviously go into his work and sort out... My daughter was, you know she is quite anxious anyway so that was quite upsetting, and my son was away at Uni so that...you know what it's like, mums are always there, and nothing happens to mums. (Sue)

\section{Employment impacts}

Both women worked full time in stressful jobs before the diagnosis but were treated quite differently. Sue was supported throughout and had 6 months' full pay but had to return to work earlier than she would like as her pay had dropped to half. She also could not take further leave until 2023 due to her government-sector employer's use of a rolling 4-year programme for sickness leave. Mary only received 24 weeks' statutory sick pay, necessitating government financial help to just meet her needs:

I've gone to the Government. Never had to do it. I don't want to do it. Feel I shouldn't be doing it. I get Universal credit and high-level mobility allowance (PIP). I would be up the creek without a paddle. If I hadn't got high-level PIP I'd be $£ 500$ short a month. My rent is $£ 720$ per month. I've just had to fight. You don't need the worry and stress on top of cancer. (Mary)

Mary had been off work for over a year, and a bout of illness and her emotional state have delayed her return to work. She is due to retire in 2020 and has decided to return to work for 15 hours per week, necessitating relinquishing her senior role.

\section{Out-of-pocket expenses}

Mary and Sue had one wig each provided by the National Health Service and they purchased another. They also bought more clothes due to surgery and weight increase. Mary paid for permanent eyebrows and Sue purchased products for sensitive skin:

I had to buy headscarves and new bras ( $£ 15$ each). I had to buy new clothes...I was recommended to use a cream...when I was having chemo to use it like twice a day and obviously when radiotherapy and that's like $£ 8$ a bottle and I was getting through one of them probably every twoweeks... You can't use normal shampoo, or body wash because of the perfume...react with your skin because it is delicate. Toothpaste, I had to buy baby toothbrushes so that they are very soft because of my gums umm yeah so it does affect most places really. (Sue)

Other direct costs included trips to the hospital for diagnosis treatment-at least 30 . There is ongoing treatment for Mary and follow-up checks for both. Mary was reimbursed her travel cost, but Sue was not. Overall, treatment for breast cancer adds considerable direct costs to the sufferer and the family.

\section{Professionals' perspectives}

The consultant practitioner $(\mathrm{CP})$ sees patients at the time of diagnosis and the nurse practitioner (NP) supports patients and their families. They both felt that chemotherapy should be used selectively for patients who need it to improve prognosis, rather than giving it to all because of the risk of morbidity such as neutropenia and leukaemia, and mortality:

...we had a group of patients who we said 'you don't need chemo' and a group of patients where we said 'oh we think you should have chemo' and a big group of patients in the middle where we are going 'umm well we think it can have some benefit' and you sit with the patient and go 'well you know chemotherapy may have a role to play and we are not sure but it has got its downside and it is horrible. (CP)

They also discussed the psychological impacts of cancer and chemotherapy:

...different people cope with it during the four months differently but it is unpleasant at the time but you see a lot of patients in whom their cognitive function is never quite the same afterwards....(CP)

...people will talk about 'chemo brain' and after, well whilst having chemotherapy and then also some time afterwards, it is a real cotton wool head feeling, you feel a bit forgetful and I have people even six months to a year down the line saying 'I have still got like this chemo brain' ... also their outlook on their career and things change as well .... (NP)

The NP confirmed that families often face financial costs that include travel and time for treatment, home care, childcare and animal care during chemotherapy. Changes in work status add to the financial hardship to cover living costs: 
...I know one workplace that literally only paid six weeks' full time pay and then three weeks' half pay and then it was Statutory Sick Pay and you imagine if you're having your chemo like say five to six months of treatment and you are out of work for that amount of time because...you physically can't work, then, and you have got a mortgage to pay, you may have a car that you are paying off and you have got kids at school, you have got childcare you know the cost implication in chemotherapy for patients and their welfare side is, is huge... (NP)

The NP reported the need for counselling long after cancer treatment:

...we do a lot of counselling for children that have seen their parents go through chemotherapy and I know one of my breast cancer patients....she is a few years ago post-treatment but her son is now being affected by the fact that she had to have chemotherapy ...he... keeps still seeing his mum without hair ...he is worried about the cancer coming back now... ... all these thoughts are now coming back to him. (NP)

\section{DISCUSSION}

This analysis demonstrates that use of chemotherapy for the treatment of early breast cancer imposes substantial and far-reaching costs well beyond those associated with the actual treatment itself. The greatest burden accrued to society from patient productivity losses. Patient out-ofpocket expenses and costs of informal care were smaller by comparison but nevertheless significant. The participants who had been through the chemotherapy process for early-stage breast cancer emphasised these costs to themselves and their informal carers. These findings support research in the USA, showing the real financial burden to patients, where over one-third of patients worried about the costs and reduced food purchases and one-fifth had lost their homes. ${ }^{27}$ The healthcare system is different in the USA and patients often have to pay for treatment, nevertheless, not being able to work to pay daily household bills affected both women interviewed for this research. In addition, interviews with participants and health practitioners highlighted that the psychological aspects of chemotherapy ripple through the social world of patients with breast cancer, often with longlasting effects.

To our knowledge, this was the first study providing cost estimates attributable specifically to the use of chemotherapy for early breast cancer in the UK. Other published studies have looked more generally at the overall costs associated with breast cancer. These suggest that early mortality costs for breast cancer in the UK fall between $£ 307.9$ million and $£ 8968$ million, ${ }^{6-8}$ while morbidityrelated costs arising from work absence have been estimated to be between $£ 59$ million and $£ 184.8$ million. ${ }^{68}$ Estimates for the costs of informal caregiving for patients with breast cancer range between £115.9million and $£ 309$ million. ${ }^{6} 8$

Our estimates are comprehensive, and we examined different approaches to estimating informal care costs. The base case involved productivity losses associated with time taken off work by carers. However, to capture the additional impact on emotional well-being, which is recognised but not widely measured in monetary terms, we conducted a secondary analysis using a well-being valuation method.$^{28}$ Further research is needed to understand the impacts of emotional and psychological effects on patients, as raised in the interviews, and the associated societal costs.

Long-term mortality costs were limited to those associated with incidence of acute myeloid leukaemia and myelodysplastic syndrome since these are frequently reported following chemotherapy use. Accounting for a fuller range of relevant malignancies and events may generate higher estimates. Out-of-pocket costs were based on a large patient survey detailing different cost components for all types of patients with cancer and reporting average costs per month and the proportion of patients facing these additional costs. ${ }^{29}$ Our estimations necessitated assumptions about what expenses could reasonably be attributed to chemotherapy for breast cancer and, although we tested the impact of these through sensitivity analyses, data specifically for the target population would likely generate more robust estimates.

More generally, we acknowledge that COI estimates such as these are only able to identify the consequences of an illness and attach monetary valuations. ${ }^{30}$ They do not convey information on related outcomes or efficiency and may present estimation and interpretation challenges. ${ }^{25}$ However, understanding the overall burden of an illness serves several important uses. ${ }^{30}$ They can help identify the main cost components and their incidence; describe the relative magnitude of overall costs at national level and explain variability of costs (eg, by disease severity, demographic and socioeconomic factors). This can then help decision makers prioritise spending and better plan future service provision. ${ }^{31}$

\section{CONCLUSION}

While medical need will ultimately drive individual-level treatment decisions, our demonstration of the size and extent of costs falling beyond healthcare suggest that treatment and commissioning decisions for adjuvant chemotherapy need to incorporate a much fuller consideration of benefits, harms and wider costs. These wider costs and societal perspective should be considered in commissioning guidelines so as to ensure chemotherapy is better targeted at those who most need it and to avoid placing unnecessary costs on patients, their caregivers and wider society.

Acknowledgements The authors wish to thank the charities Macmillan, Carers UK and the Big C for their help on data collection and participant recruitment. 
Many thanks to all the stakeholders who helped to shape the research and thanks especially to the patients and staff who kindly gave time to be interviewed.

Contributors RF, AS, KP, AP and SHW-conception, design and receiving funding for the study. KP and SHW-data collection and analysis. SHW, KP, AS, AP and RF-drafting and reviewing the manuscript for publication.

Funding Exact Sciences (previously Genomic Health) UK financially supported the study.

Disclaimer The funders did not provide input into the research at any stage.

Competing interests None declared.

Patient consent for publication Not required.

Ethics approval The University of East Anglia's Ethics Committee approved this research (number 201 819-132).

Provenance and peer review Not commissioned; externally peer reviewed.

Data availability statement All data relevant to the study are included in the article or uploaded as supplemental information. All data used for the modelling are available in a supplemental file containing tables A-F.

Supplemental material This content has been supplied by the author(s). It has not been vetted by BMJ Publishing Group Limited (BMJ) and may not have been peer-reviewed. Any opinions or recommendations discussed are solely those of the author(s) and are not endorsed by BMJ. BMJ disclaims all liability and responsibility arising from any reliance placed on the content. Where the content includes any translated material, BMJ does not warrant the accuracy and reliability of the translations (including but not limited to local regulations, clinical guidelines, terminology, drug names and drug dosages), and is not responsible for any error and/or omissions arising from translation and adaptation or otherwise.

Open access This is an open access article distributed in accordance with the Creative Commons Attribution Non Commercial (CC BY-NC 4.0) license, which permits others to distribute, remix, adapt, build upon this work non-commercially, and license their derivative works on different terms, provided the original work is properly cited, appropriate credit is given, any changes made indicated, and the use is non-commercial. See: http://creativecommons.org/licenses/by-nc/4.0/.

\section{ORCID iDs}

Stephanie Howard Wilsher http://orcid.org/0000-0002-3060-3270

Richard Fordham http://orcid.org/0000-0002-5520-6255

\section{REFERENCES}

1 World Cancer Research Fund. Breast cancer statistics. Available: https://www.wcrf.org/dietandcancer/cancer-trends/breast-cancerstatistics

2 Cancer Research. Breast cancer statistics. Available: https://www. cancerresearchuk.org/health-professional/cancer-statistics/statisticsby-cancer-type/breast-cancer\#heading-Five

3 National Institute for Health and Care Excellence. Early and locally advanced breast cancer: diagnosis and management. NICE guideline [NG101] 2018.

4 National Cancer Registry and Analysis Dataset. Chemotherapy, radiotherapy and surgical tumour resections in England. treatment breakdown, 2013-2015. Available: https://www.cancerdata.nhs.uk/ treatments [Accessed $17 \mathrm{Jul}$ 2019].

5 National Instutute for Health and Care Excellence. Tumour profiling tests to guide adjuvant chemotherapy decisions in early breast cancer. Diagnostics guidance [DG34], 2018. Available: https://www. nice.org.uk/guidance/dg34 [Accessed 17 Jul 2019].

6 Burns R, Leal J, Sullivan R, et al. Economic burden of malignant blood disorders across Europe: a population-based cost analysis. Lancet Haematol 2016;3:e362-70.

7 Hanly PA, Sharp L. The cost of lost productivity due to premature cancer-related mortality: an economic measure of the cancer burden. BMC Cancer 2014;14:224

8 Luengo-Fernandez R, Leal J, Gray A, et al. Economic burden of cancer across the European Union: a population-based cost analysis. Lancet Oncol 2013;14:1165-74.

9 Round J, Jones L, Morris S. Estimating the cost of caring for people with cancer at the end of life: a modelling study. Palliat Med 2015;29:899-907.

10 World Health Organization. International statistical classification of diseases and related health problems 10th revision (ICD-10)-WHO version for 2016. Chapter II: Neoplasms (C00-D48). Available: https:// icd.who.int/browse10/2016/en\#/II [Accessed 17 Jul 2019].
11 Larg A, Moss JR. Cost-of-illness studies: a guide to critical evaluation. Pharmacoeconomics 2011;29:653-71.

12 Office for National Statistics. Cancer registration statistics, England, 2019b. Available: https://www.ons.gov.uk/peoplepopulationandc ommunity/healthandsocialcare/conditionsanddiseases/datasets/canc erregistrationstatisticscancerregistrationstatisticsengland [Accessed 17 Jul 2019].

13 Information Services Division Scotland. Cancer incidence and prevalence in Scotland (to December 2017), 2019. Available: https:// www.isdscotland.org/Health-Topics/Cancer/Publications/datatables2017.asp?Co=Y [Accessed 17 Jul 2019].

14 Welsh Cancer Intelligence and Surveillance Unit. Cancer incidence in Wales, 2001-2016: dashboard \& data, 2019. Available: http:// www.wcisu.wales.nhs.uk/dashboard-data-5 [Accessed 17 Jul 2019].

15 Northern Ireland Cancer Registry. Incidence, prevalence and survival statistics: 1993-2017. Available: www.qub.ac.uk/research-centres/ nicr/CancerInformation/official-statistics/BySite/all-cancers/ [Accessed 17 Jul 2019].

16 United Kingdom and Ireland Association of cancer Registries. Performance indicators: \% of cases treated with chemotherapy, 2019. Available: www.ukiacr.org/kpis [Accessed 17 Jul 2019].

17 SACT system anti-cancer therapy chemotherapy dataset. 2019. 30 day mortality SACT 2015_2016 public final. Available: http://www. chemodataset.nhs.uk/home [Accessed 17 Jul 2019].

18 European Cancer Information System. Age-specific 5-year relative survival, 2019. Available: https://ecis.jrc.ec.europa.eu/explorer.php?\$ 0-2\$1-UKE,UKN,UKS,UKW,UK\$2-All\$4-1,2\$3-65\$6-0,14\$5-2000, 2007\$7-1\$CRelativeSurvivalAgeGroup\$X0_14-\$X0_15-RSC\$CRel ativeSurvivalFollow \$X1 14-\$X1_-1-\$X1_15-RSC [Accessed $17 \mathrm{Jul}$ 2019].

19 Office for National Statistics. Earnings and hours worked, age group: ASHE table 6, 2018. Available: https://www.ons.gov.uk/empl oymentandlabourmarket/peopleinwork/earningsandworkinghours/ datasets/agegroupashetable6 [Accessed 17 Jul 2019].

20 Office for National Statistics. Labour market participation rates by age and sex, UK: 1995, 2005, 2015 and 2017, 2018. Available: https://www.ons.gov.uk/employmentandlabourmarket/peopleinwork/ employmentandemployeetypes/adhocs/009385labourmarketpartic ipationratesbyageandsexuk199520052015and2017 [Accessed 17 Jul 2019].

21 Office for National Statistics. A05 NSA: employment, unemployment and economic inactivity by age group (not seasonally adjusted), 2019. Available: https://www.ons.gov.uk/employmentandlabourm arket/peopleinwork/employmentandemployeetypes/datasets/empl oymentunemploymentandeconomicinactivitybyagegroupnotseasonal lyadjusteda05nsa [Accessed 17 Jul 2019].

22 Office for National Statistics. Labour market statistics: whole economy year on year three month average growth (\%): seasonally adjusted total pay excluding arrears, 2019. Available: https://www. ons.gov.uk/employmentandlabourmarket/peopleinwork/earnings andworkinghours/timeseries/kac3/Ims [Accessed 17 Jul 2019].

23 Hall E, Johnson L, Atkins N, et al. 430 cross-sectional study of quality of life (QL) 6 years after start of treatment in the UK Taxotere as adjuvant chemotherapy trial (TACT; CRUK01/001). Europ J Cancer Supple 2010;8:184.

24 Azim HA, de Azambuja E, Colozza M, et al. Long-term toxic effects of adjuvant chemotherapy in breast cancer. Ann Oncol 2011:22:1939-47.

25 Macmillan Cancer Support. The rich picture: cancer carers. understanding the numbers, needs and experiences of cancer carers in the UK, 2016.

26 Ipsos MORI and Macmillan Cancer Support. More than a million. Understanding the UK's carers of people with cancer - a report by Ipsos Mori for macmillan cancer support, 2011.

27 Jagsi R, Ward KC, Abrahamse $\mathrm{PH}$, et al. Unmet need for clinician engagement regarding financial toxicity after diagnosis of breast cancer. Cancer 2018;124:3668-76.

28 McDonald R, Powdthavee N. The shadow prices of voluntary caregiving: using panel data of well-being to estimate the cost of informal care. IZA DP No. 11545, 2018.

29 Macmillan Cancer Support. Cancer's hidden price tag - revealing the costs behind the illness. Revealing the costs behind the illness 2013, 2013. Available: https://www.macmillan.org.uk/_images/CancersHidden-Price-Tag-report-England_tcm9-270862.pdf [Accessed 17 Jul 2019].

30 Patel A. Economic costs of mental illness. In: Bhugra D BK, Yeung S, Wong S, et al, eds. Oxford textbook of public mental health. Oxford: Oxford University Press, 2018.

31 Tarricone R. Cost-of-illness analysis. what room in health economics? Health Policy 2006;77:51-63. 
32 Office for National Statistics. Population mid-year estimate, 2018. Available: https://www.ons.gov.uk/peoplepopulationandcommunity/ populationandmigration/populationestimates [Accessed $17 \mathrm{Jul}$ 2019].

33 Office for National Statistics. Regional gross disposable household income, UK: 1997 to 2017. annual estimates of regional gross disposable household income (GDHI) for the UK NUTS1, NUTS2, NUTS3 regions, local and combined authorities, City regions and other economic and enterprise regions, 2019. Available: https://www. ons.gov.uk/economy/regionalaccounts/grossdisposablehousehold income/bulletins/regionalgrossdisposablehouseholdincomegdhi/ 1997to2017 [Accessed 17 Jul 2019].
34 National Institute for Health and Care Excellence Excellence,. NICE methods quide updates, 2013.

35 Office for National Statistics. National life tables: UK, 2018. Available: https://www.ons.gov.uk/peoplepopulationandcommunity/birthsde athsandmarriages/lifeexpectancies/datasets/nationallifetablesunited kingdomreferencetables [Accessed 17 Jul 2019].

36 Office for National Statistics. Inflation and price indices, 2019 Available: https://www.ons.gov.uk/economy/inflationandpriceindices [Accessed 17 Jul 2019].

37 Personal Social Services Research Unit. Unit costs of health and social care 2018, 2018. Available: https://www.pssru.ac.uk/projectpages/unit-costs/unit-costs-2018/ [Accessed 17 Jul 2019]. 